\title{
Calibration of a Ground-Water-Flow Model by Regression
}

By Paul E. Misut and Elizabeth R. McNew-Cartwright

U.S. GEOLOGICAL SURVEY

Open-File Report 95-388

Prepared in cooperation with the SUFFOLK COUNTY WATER AUTHORITY

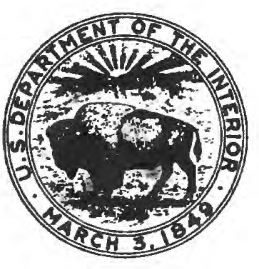

Coram, New York 


\section{U.S. DEPARTMENT OF THE INTERIOR BRUCE BABBITT, Secretary}

U.S. Geological Survey

Gordon P. Eaton, Director

For additional information write to:

U.S. Geological Survey 2045 Route 112, Bldg. 4 Coram, NY 11727
Copies of this report may be purchased from:

U.S. Geological Survey Earth Science Information Center Open-File Reports Section P.O. Box 25286, MS 517 Denver Federal Center Denver, CO 80225 


\section{CONTENTS}

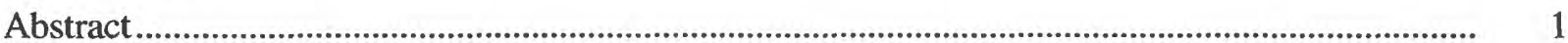

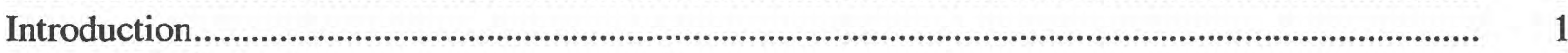

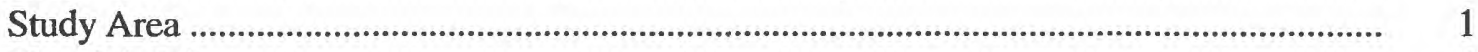

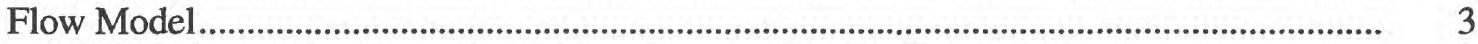

Nonlinear regression procedure for estimating recharge and hydraulic conductivity ......................... 7

Summary and Conclusions ................................................................................................................. 11

References cited ...................................................................................................................... 11

\section{FIGURES}

1. Map of location of study area and altitude of saltwater interface in the study area on the North Fork of Long Island, N.Y.

2. Map of altitude of water table and location of observation wells on the North Fork of Long Island, N.Y.

3. Annual spring ground-water levels and annual winter precipitation at Greenport, N.Y., 1952-92

4. Block diagram showing model geometry and boundary conditions

5. Calibration points in modeled area on the North Fork of Long Island, N.Y.

6. Residuals of estimated uniform conductivity and recharge parameters by (a) model row and (b) model column

\section{TABLES}

1. MODFLOWP parameter estimates and goodness-of-fit for three simulations with differing hydraulic conductivity zonations. 


\section{CONVERSION FACTORS, ABBREVIATIONS AND VERTICAL DATUM}

Multiply

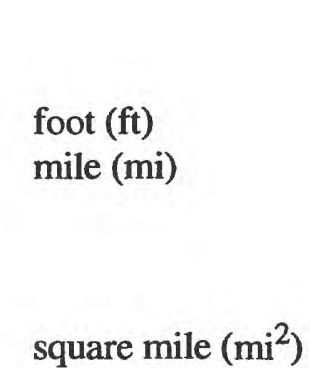

By

\section{Length}

0.3048

1.609

Area

2.59
To Obtain

meter

kilometer

square kilometer

Sea level: In this report, "sea level" refers to the National Geodetic Vertical Datum of 1929 (NGVD of 1929)--a geodetic datum derived from a general adjustment of the firstorder level nets of the United States and Canada, formerly called Sea Level Datum of 1929. 


\title{
CALIBRATION OF A GROUND-WATER-FLOW MODEL BY REGRESSION
}

\author{
By Paul E. Misut and Elizabeth R. McNew-Cartwright
}

\begin{abstract}
Net areal recharge and aquifer hydraulic conductivity values for calibration of a transient-state ground-water-flow model were estimated through a nonlinear regression technique that minimizes the sum of squared weighted differences between observed and simulated water levels. The estimates of these terms were obtained through regression of water levels simulated by the U.S. Geological Survey's modular flow model (MODFLOW). Model-parameter data that are independent of water-level observations can be used to force the regression to yield parameter estimates that are close to expected values.

The study area encompasses 17 square kilometers on the North Fork of Long Island, N.Y. It was simulated as (1) having uniform recharge and hydraulic conductivity values throughout, and (2) divided into two zones of differing hydraulic conductivity. The transient-state model is designed with eight time steps of differing stress that together represent about 1 year. Results of parameter estimation by regression analysis indicate that an accurate calibration can be achieved without the conventional trial-and-error approach.
\end{abstract}

\section{INTRODUCTION}

One difficulty in the use of ground-water flow modeling in water-resources planning and management is the expense of the conventional trial-and-error calibration procedure. Because reliable methods of measuring certain model-input parameters, such as recharge, have not been developed, many simulations are required for trial-and-error adjustment of even the most soundly conceptualized model. Uncertainties in model conceptualization and inadequate data increase the number of simulations required. Thus, alternatives to the conventional trial-and-error procedure are needed to minimize the number of simulations required for sufficient calibration.

This paper demonstrates an alternative calibration technique as applied to a ground-water flow model of the $17-\mathrm{km}^{2}$ Greenport area on the North Fork peninsula of Long Island, N.Y. (fig. 1). In 1989, the U.S. Geological Survey (USGS), in cooperation with the Suffolk County Department of Health Services and the Suffolk County Water Authority, began a 4-year study to define the ground-water flow system and simulate transient-state conditions with MODFLOW, the USGS modular finite-difference ground-water flow model (McDonald and Harbaugh, 1988). In this study, the conventional calibration procedure of input-parameter adjustment by trial and error is replaced by a parameter-estimation technique that uses regression of simulated water levels in relation to observed water levels. The parameter-estimation technique is incorporated with MODFLOW by the computer program MODFLOWP (Hill, 1992).

\section{Study Area}

The study area encompasses part of a glacial end moraine of Pleistocene age. Coastal erosion has removed much of the north-shore ridge material and left bluffs above narrow beaches strewn with cobbles and boulders; the area south of the morainal ridge is a pitted outwash plain (Crandell, 1963). Boreholegeophysical logs from wells in the study area display the typicalcharacteristics of the Long Island Pleistocene deposition-coarse-grained glacial sand and gravel deposits with interspersed clay lenses. Results of specific-capacity tests of wells within the study area, calculated with a modified Theis method 


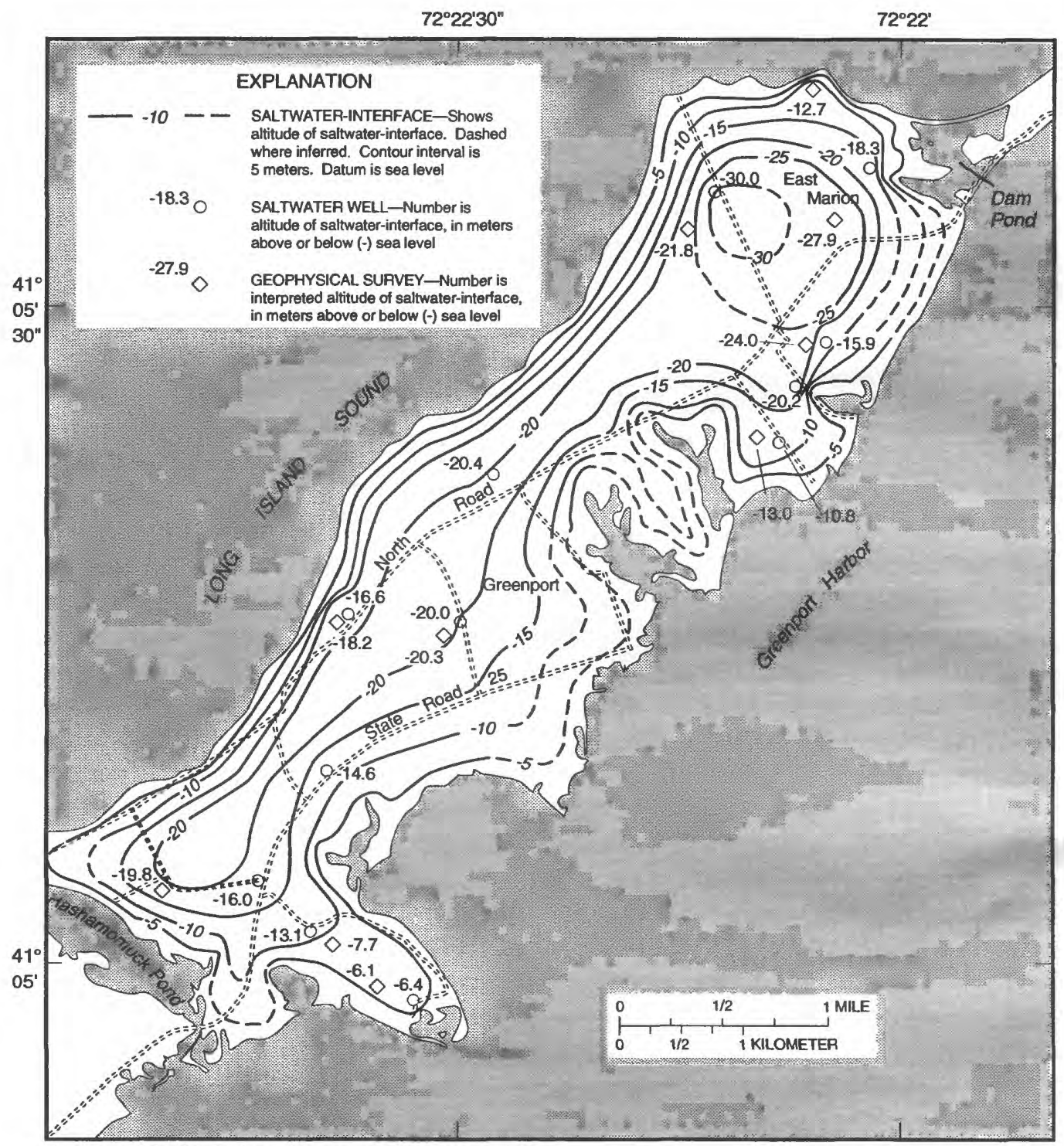

Base from New York State Department of Transportation,

Southold, Greenport, and Orient quadrangles, 1981, 1:24,000

Figure 1. Location of study area and altitude of saltwater interface in the study area on the North Fork of Long Island, N.Y. (Modified from McNew- Cartwright and Arav, 1995.) 
(McClymonds and Franke, 1972), indicate that the horizontal hydraulic conductivity of the end moraine is about $90 \mathrm{~m} / \mathrm{d}$.

The shoreline represents the outline of the freshwater lens, which lies entirely within the glacial deposits. The lateral boundaries of the freshwater lens are Long Island Sound to the north, Greenport Harbor to the south, Hashamomuck Pond to the west, and Dam Pond to the east (fig. 1). The approximate altitude of the bottom of the lens (the freshwater-saltwater interface), as interpreted from water-quality sampling of wells and surface geophysical surveys, is also indicated in figure 1. The freshwater-saltwater interface was not observed to move beyond a zone of tide-induced mixing during the 4-year study. The approximate altitude of the water table on October 4, 1989, and locations of observation wells are shown in figure 2 . An assumed aquifer porosity of 0.3 gives a total freshwater-lens volume of about 64 million cubic meters.

Ground-water discharge occurs primarily as lateral and upward seepage to tidal wetlands and adjacent saltwater bodies. Measurement of discharge to gaining streams, which are common in the main part of Long Island to the west, was infeasible in the study area because the area contains no major streams. Public-supply pumpage totals about 34 million liters per year, and much of this volume is lost from the ground-water system as wastewater outflow to Greenport Harbor.

All freshwater in the aquifer originates as precipitation. Mean annual precipitation is about $121 \mathrm{~cm}$ (Roy F. Weston, 1992). Infiltration studies conducted at the Cornell University agricultural experiment station on eastem Long Island suggest that, in the island's agricultural districts, most recharge results from precipitation between October 15 and March 15 (Steenhuis and others, 1985). Virtually all summer rainfall evaporates or is transpired. Water levels at a shallow observation well located at the intersection of North Road and Moore Lane (fig. 1) are plotted in figure 3 with annual winter precipitation measured from October 15 through March 15. March water levels are shown because they represent levels attained at the end of the yearly period of recharge. Apart from anomalies caused by rainfall near the time of measurement and by well pumping, water-table fluctuations in the study-area water table parallel fluctuations in winter precipitation.

\section{Flow Model}

MODFLOW simulates ground-water flow by solving a finite-difference approximation of the ground-water flow equation. The model grid is constructed of 26 rows and 57 columns and forms a total of 1,482 square cells, each measuring $152.4 \mathrm{~m}$ on the side. The 739 active cells represent an area of $17 \mathrm{~km}^{2}$. Flow is simulated as a single, unconfined layer, the thickness of which is a variable calculated as the difference in elevation between the water table and the freshwater-saltwater interface. Model geometry and boundary conditions are depicted in figure 4. Recharge from precipitation is through the top face of model cells; discharge to saltwater bodies and tidal wetlands is represented by constant-head cells along the coast, at the perimeter of the active model area. The freshwater-saltwater interface is a stationary, impermeable boundary. The configuration of constant-head cells and the elevation of the bottom face of active cells are held constant. Well pumpage is treated as a specified-flux boundary condition at four cells in the active area (fig. 4) corresponding to locations of well fields. Pumpage is varied by transient-state stress periods to reflect seasonal changes - ground-water use increases during the summer, when visitors outnumber permanent residents. A total of $190,000 \mathrm{~m}^{3}$ is pumped in the 355 days simulated. The transientstate-model water budget balances recharge with discharge and change in storage. In all stress periods, the change in storage is minimal, and recharge is therefore about equal to discharge. 


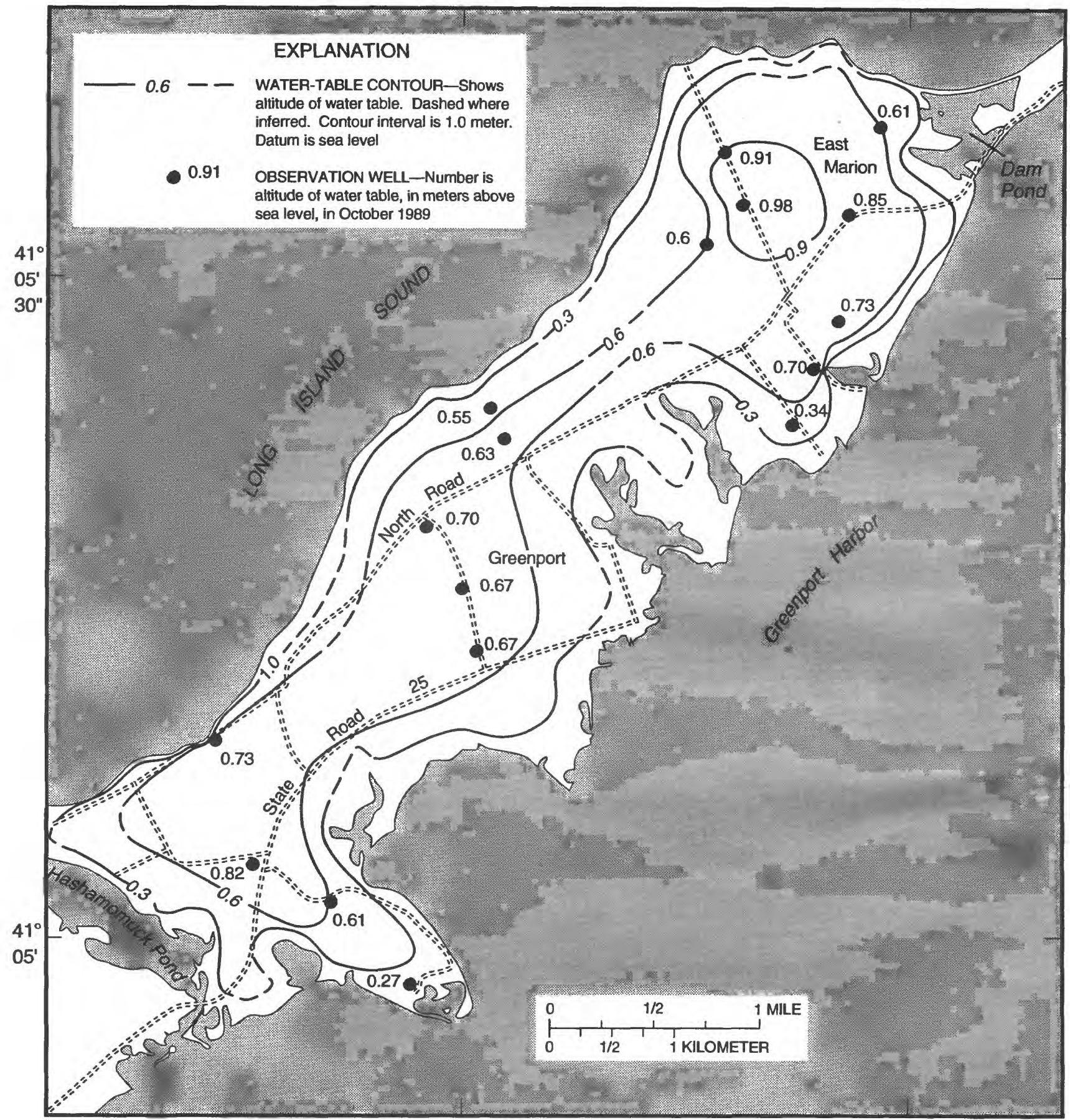

Base from New York State Department of Transportation,

Southold, Greenport, and Orient quadrangles, 1981, 1:24,000

Figure 2. Altitude of the water table and location of observation wells on the North Fork of Long Island, N.Y. (Modified from McNew-Cartwright and Arav, 1995.) 


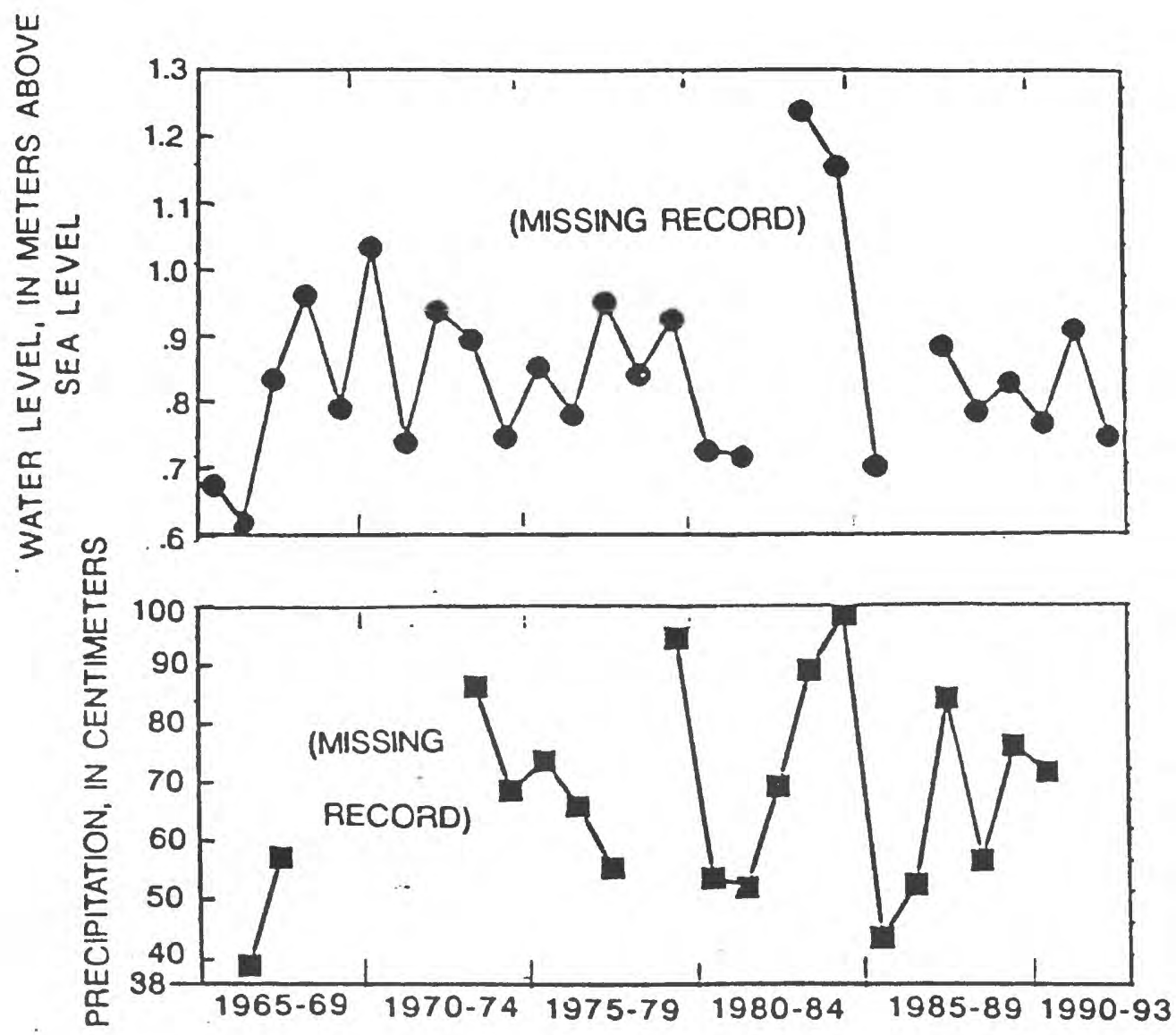

EXPLANATION

ANNUAL SPRING WATER LEVEL IN WELL S-16783-Measured early april. Generally represents annual high.

$\rightarrow$ ANNUAL WINTER PRECIPITATION AT GREENPORT-. Total from October 15 to March 15.

Figure 3. Annual spring ground-water levels and annual winter precipitation at Greenport, N.Y.,1965-92. 


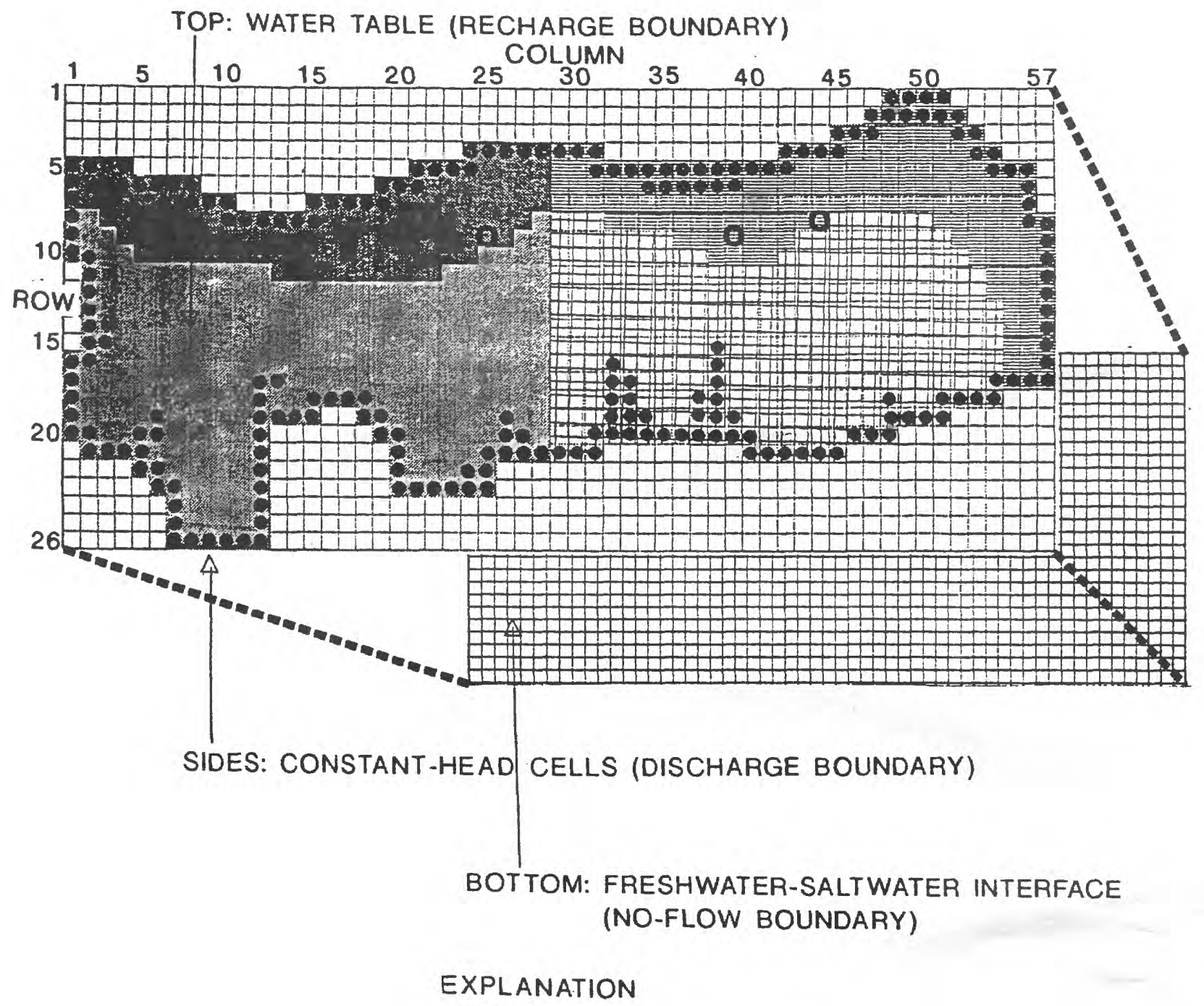

WESTERN MORAINE ZONE (CLAY)

$\square$ WESTERN OUTWASH ZONE (CLAY)

䁖EASTERN MORAINE ZONE (NON CLAY)

EEASTERN OUTWASH ZONE (NON CLAY)

- pumped well

- CONSTANT-HEAD BOUNDARY CELLS

Figure 4. Block diagram showing model geometry and boundary conditions. 


\section{NONLINEAR REGRESSION PROCEDURE FOR ESTIMATING RECHARGE AND HYDRAULIC CONDUCTIVITY}

Regression analysis of simulated heads in relation to observed heads was conducted to optimize recharge and hydraulic conductivity parameters. Five sets of freshwater-level measurements were made at 24 observation wells on October 4, 1989; March 13, 1990; June 12, 1990; July 23, 1990; and September 20,1990 . Observations were not equally reliable, and it could not be assumed that the differences between observed and simulated values have the statistical properties required to produce a valid regression, even if the simulated values are correct (Hill, 1992). Observation weighting was applied through a MODFLOWP procedure to assign a relative significance to each of the observations on the basis of inaccuracies in the water-level measurements resulting from (1) inaccuracies in well leveling and (2) fluctuations caused by tides. Locations and relative weighting of observation points are indicated in figure 5.

Data on model parameters that are independent of water-level observations used in regression analysis are here termed "prior information" (Hill, 1992). Prior information was applied because simulated water levels increase if either an increase in recharge or a decrease in hydraulic conductivity is specified, and, given freedom to simultaneously estimate recharge and conductivity at any value for which the differences between the simulated and observed water levels are minimized, convergence on realistic estimates does not occur. Therefore, prior information in the form of a natural log-normal probability distribution on the hydraulic conductivity parameter (based on specific-capacity tests) was incorporated into the nonlinear regression (Cooley and Naff, 1990, p. 72-74). Estimates of hydraulic conductivity and recharge remain within the realistic ranges (in general agreement with previous studies).

A MODFLOWP solution that assumes recharge and hydraulic conductivity to be uniform throughout the study area and used a prior hydraulic conductivity mean of $91.1 \mathrm{~m} / \mathrm{d}$ and natural $\log$-space standard deviation of $0.4 \mathrm{~m} / \mathrm{d}$ estimated the mean recharge rate at $35.8 \mathrm{~cm} / \mathrm{yr}$ and hydraulic conductivity at $93.6 \mathrm{~m} / \mathrm{d}$. Estimates of recharge by previous investigators are generally equal to about one-half of the mean annual precipitation, or about $56 \mathrm{~cm} / \mathrm{yr}$. This value is 60 percent larger than the estimate obtained by use of regression. The discrepancy may be due to the specification of prior information on hydraulic conductivity. The estimated recharge value can be increased by either (1) increasing the mean or (2) increasing the standard deviation of the prior hydraulic conductivity because the ratio of estimated recharge to hydraulic conductivity is constant. Specific-capacity tests of the upper glacial aquifer in other areas of Long Island have suggested higher hydraulic conductivity values (Prince and Schneider, 1989).

The model fit corresponding to the MODFLOWP solution that yielded a recharge estimate of $35.8 \mathrm{~cm} / \mathrm{yr}$ is illustrated in figure 6 , in which weighted residuals are plotted as functions of row and column of the model cell corresponding to the location of the water-level measurement. Positive residuals indicate that the simulated water levels were lower than observed, and negative residuals indicate that they were higher. The largest positive residual is at column 43, row 10, in the north-shore moraine, and the largest negative residual is at column 41, row 18, in the south-shore outwash plain. A grouping of negative residuals also is evident in the eastern part of the study area (model columns numbered 15 and higher), and positive residuals in the western part (model columns numbered less than 41). These patterns could be caused by local differences in hydraulic conductivity, which is generally greater in outwash deposits than moraine deposits; also, clay lenses are more prevalent in the westem part than in the eastern part. Proximity to model boundaries also can affect residuals; for example, the simulated waterlevel is probably lower than the observed level if (1) the observation is near a near a constant-head boundary, or (2) if conductivity in an area of drawdown is greater than the uniform parameter estimate for the entire study area. Coarseness of model discretization contributes to these discrepancies.

Two additional hydraulic conductivity zonations were tested for improvement in model calibration (zonation boundaries are shown in figure 4)-(1) uniform recharge with hydraulic conductivity divided into moraine and outwash zones to reflect the greater conductivity of outwash, and (2) uniform recharge with hydraulic conductivity divided into eastern and western zones to represent the greater prevalence of clay (hence lower conductivity) in the west; results are given in table 1. The sum of squared residuals 


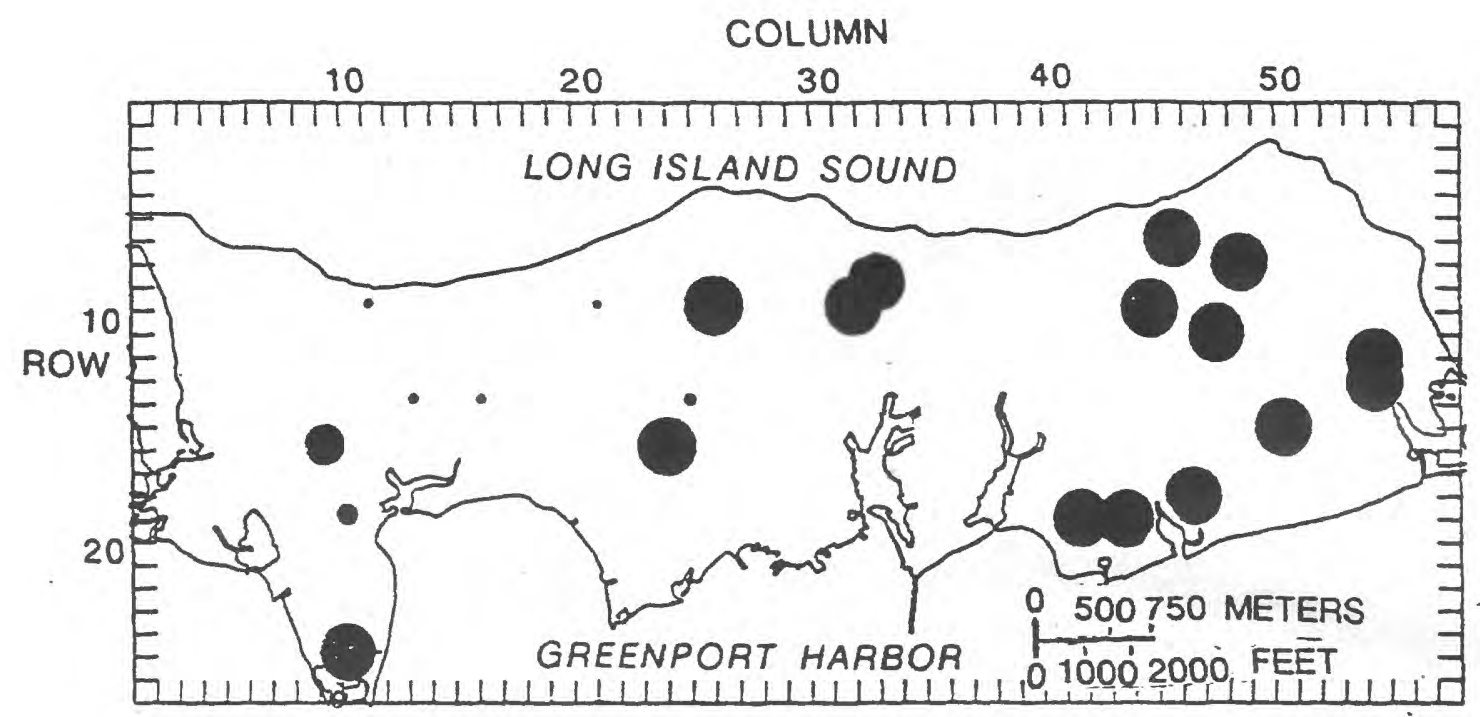

\section{EXPLANATION}

- MODEL-CALIBRATION POINTS (WELL LOCATIONS)-Symbol size indicates relative significance of waterlevel observation to the calibration procedure

Figure 5. Calibration points in modeled area on the North Fork of Long Island, N.Y. 
(RSSQ) is a measure of the goodness of fit of the computed regression equations that optimize parameter values; a decrease in RSSQ indicates an improvement in calibration. The east-west zonation gave a lower RSSQ value than the uniform-values condition, confirming that separate values for the eastern and western zones was effective and providing a quantitative measure of the improvement in model calibration. Zonation into moraine and outwash areas did not significantly improve model calibration.

Table 1. MODFLOWP parameter estimates and goodness-of-fit for three simulations with differing hydraulic conductivity zonations

[Hydraulic conductivity in meters per day; recharge in centimeters per year; RSSQ, sum of squared residuals, a statistical measure of goodness of fit]

\begin{tabular}{|c|c|c|c|}
\hline & \multicolumn{3}{|c|}{ Hydraulic conductivity zonation } \\
\hline & $\begin{array}{c}1 \\
\text { (Uniform) }\end{array}$ & $\begin{array}{c}2 \\
\text { (Moraine- } \\
\text { Outwash) }\end{array}$ & $\begin{array}{c}3 \\
\text { (East-west) }\end{array}$ \\
\hline \multicolumn{4}{|l|}{ Hydraulic conductivity ${ }^{1}$} \\
\hline Uniform study-area distribution & 93.6 & & \\
\hline Moraine zone & & 89.3 & \\
\hline Outwash zone & & 95.7 & \\
\hline East (nonclay) zone & & & 107.0 \\
\hline West (clay) zone & & & 76.8 \\
\hline Recharge & 35.8 & 35.8 & 32.8 \\
\hline RSSQ & 2,033 & 2,026 & 1,772 \\
\hline
\end{tabular}

${ }^{1}$ Hydraulic conductivity values are back-transformed from the natural log-space for presentation purposes. 


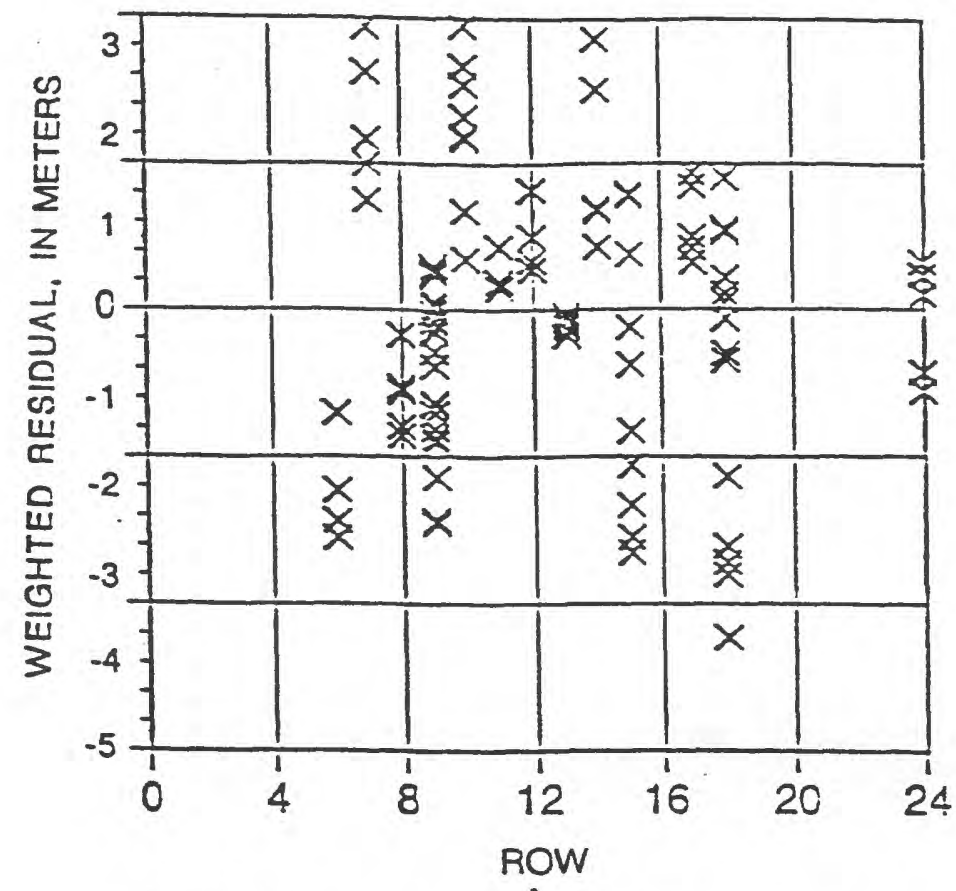

A. Weighted residuals in relation to model rows.

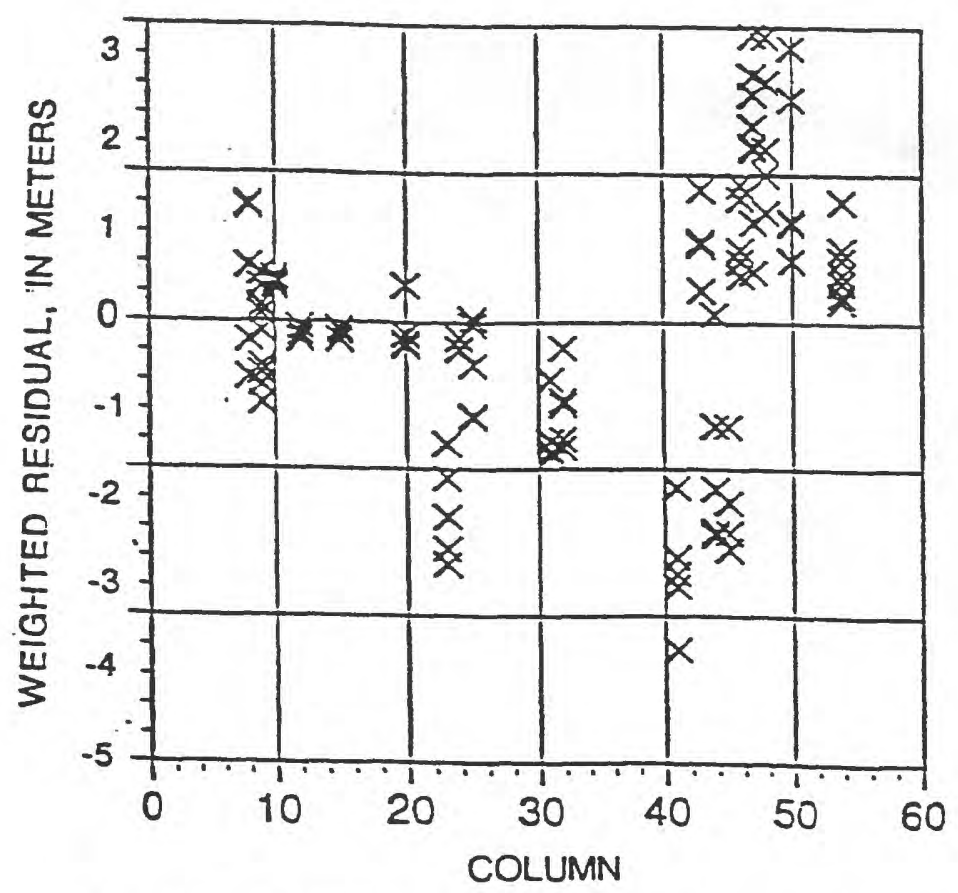

B. Weighted residuals in relation to model columns.

Figure 6. Residuals of estimated uniform conductivity and recharge parameters by (A) model row and (B) model column. 


\section{SUMMARY AND CONCLUSIONS}

Recharge and hydraulic conductivity were analyzed through the MODFLOWP regression technique. Prior information on hydraulic conductivity was obtained from field data, and observations were weighted on the basis of their relative accuracy. An estimate of uniform parameters throughout the study area resulted in groups of positive and negative residuals. The sum of squared residuals for estimations was analyzed to test hypotheses concerning zonation of the study area into moraine (north) and outwash (south) halves and clay (west) and nonclay (east) halves to reflect local differences in hydraulic conductivity. Only the clay-nonclay zonation improved the accuracy of simulated water levels and the model calibration, quantitatively measured. The simple calibration exercises discussed in this paper would have been difficult to replicate with a trial-and-error approach but were easily run with MODFLOWP because the parameter estimates reflect optimal values based on minimization of 110 weighted residuals per simulation.

\section{REFERENCES CITED}

Cooley, R.L., and Naff, R.L.,1990, Regression modeling of ground-water flow: U.S. Geological Survey Techniques of Water-Resources Investigations, Book 3, Chapter B4, 232 p.

Hill, M.C., 1992, A computer program (MODFLOWP) for estimating parameters of a transient, threedimensional, ground-water flow model using nonlinear regression: U.S. Geological Survey Open-File Report 91-484, 358 p.

McClymonds, N.E., and Franke, O.L., 1972, Water-transmitting properties of aquifers on Long Island, N.Y.: U.S. Geological Survey Professional Paper 627-E, 24 p.

McDonald, M.G., and Harbaugh, A.W., 1988, A modular three-dimensional finite-difference groundwater flow model: U. S. Geological Survey Techniques of Water-Resources Investigations of the U.S. Geological Survey, Book 6, Chapter A1, 548 p.

McNew-Cartwright, E.R., and Arav, S., 1995, Surface geophysical surveys of the freshwater-saltwater interface in a coastal area of Long Island, New York: Groundwater, v. 33, no. 4, p. 615-626.

Peterson, D.S., 1987, Ground-water recharge rates in Nassau and Suffolk Counties, New York: U.S. Geological Survey Water-Resources Investigations Report 86-4181, 19 p.

Prince, K.R., and Schneider, B.J., 1989, Estimation of hydraulic characteristics of the upper glacial and Magothy aquifers at East Meadow, New York, by use of aquifer tests: U.S. Geological Survey WaterResources Investigations Report 87-4211, 43 p.

Roy F. Weston, 1992, Draft groundwater management study report: Carle Place, N.Y., 48 p.

Smolensky, D.A., Buxton, H.T., and Shernoff, P.K., 1989, Hydrologic framework of Long Island, New York: U.S. Geological Survey Hydrologic Investigations Atlas HA-709, 3 sheets, scale 1:250,000.

Steenhuis, T.S., Jackson, C.D., Kung, S.K., and Brutsaert, W., 1985, Measurement of groundwater recharge on eastern Long Island, New York, USA: Journal of Hydrology, v. 79, p. 145-169. 